\title{
Multi-level governance in federal contexts: the Social Assistance Policy in the City of São Paulo*
}

\author{
Renata Bichir \\ Universidade de São Paulo, Brazil \\ Gabriela Horesh Brettas \\ Universidade de São Paulo, Brazil \\ Pamella Canato \\ Universidade de São Paulo, Brazil
}

This article examines the governance of social assistance in the City of São Paulo by considering the interplay between the federal normative acts that conform to the Unified System of Social Assistance (SUAS) and the decisions taken at the municipal level, in order to better understand multi-level governance in federal contexts. We demonstrate that federal-set policy parameters matter but they are not sufficient to understand how policies are implemented at the local level. Hence, the article revises some established assumptions about the local implementation of social policies in federal contexts. We argue that the governance of social assistance at the municipal level can be understood by the combination of the following aspects: 01 . the power resources, capacities and constraints available for state and civil society actors; 02. the interactions and disputes between these actors in formal and informal arenas; 03. the main ideas supported by relevant actors and the instruments they use to transform ideas into policy actions. Our results show that agency at the local level matters even for nationally regulated policies. Moreover, the historical process of capacity building matters not only to state actors, but also to civil society organizations.

Keywords: Implementation; governance; social assistance; São Paulo.

(*) http://dx.doi.org/10.1590/1981-3821201700020003

This article is one of the products of the research project "Beyond Cash Transfers? Challenges of the intersectoral articulation of social policies", coordinated by Renata Bichir at the Center for Metropolitan Studies (CEM/Cepid/Fapesp), which is funded by FAPESP (Process 2013/07616-7). 
"Sometimes we throw a rock and it does not fall on the floor"1.

Ithough this affirmation contradicts the laws of physics, it summarizes the
difficulties associated with policy implementation, especially those related to the distance between centralized decisions and their transformation into actions, services and practices involving different actors. This common distance between policy formulation and implementation (HILL and HUPE, 2009; WINTER, 2006) results from the combination of several factors: different perspectives, values and modes of framing the same issues between various actors; information asymmetries throughout the process of implementation; different institutional contexts and arrangements; and competition around resources, ideas, interests and visions concerning the implementation. Implementation itself is a process full of decisions, which might even lead to the reformulation of the policy (FARIA, 2012; SABATIER, 2007; WINTER, 2006).

These issues have been well-explored in the literature on implementation (HILL and HUPE, 2009; LIPSKY, 1983; O'TOOLE Jr., 2010; PRESSMAN and WIDALVSKY, 1984; WINTER, 2006). Our research follows a set of innovative approaches regarding implementation (HILL, 2005; HOWLETT, RAMESH and PERL, 2009), focusing on complex patterns of interaction between different organizations and actors, considering the distribution of power and responsibility as well as formal and informal processes of negotiation. The current debate on the multi-level governance arrangements highlights the need for a better understanding of the relations between the central and the subnational levels (KAZEPOV, 2005; KAZEPOV and BARBERIS, 2013).

We expect to contribute by analyzing the implementation dynamics of the social assistance policy in the City of São Paulo. Social assistance in Brazil is based upon service provision for vulnerable families, organized within different levels of complexity ${ }^{2}$, and upon benefits, including conditional cash transfer programs, like 'Bolsa Família'3, and

${ }^{1}$ Interview with a high-level bureaucrat in the Municipal Secretariat of Assistance and Social Development (SMADS), in São Paulo.

${ }^{2}$ At the basic level, services aim to prevent different types of risks and violences and to maintain family ties, including services for vulnerable children, adolescents, elders, disabled individuals, etc. At the more complex level, services aim to protect families that have been subjected to violence and/or discrimination and other types of rights abuse, such as child labor, sexual offense, among others.

3 As discussed by Bichir $(2011,2016 a)$ the policy decision-making regarding the social assistance services is less centralized and more negotiated in federative fora than that of Bolsa Família Program.

(2017) $11(2) \quad$ - $\quad$ e0003-2/28 
income benefits such as the Continuous Cash Transfer Benefit (BPC). In this article, we approach the dynamics regarding service provision. Since 2005, the policy of social assistance has been developed in the frame of a national system, known as the Unified System of Social Assistance (SUAS), which defines the responsibilities of the municipal, state and federal levels. The federal government is responsible for the general decisionmaking process, regulation, coordination, co-funding and the definition of general parameters. The municipalities oversee implementation, which occurs through the combination of service provision by the public sector and by civil society organizations (CSOs) ${ }^{4}$. The states are in charge of coordinating the actions developed at the municipal level, besides being responsible for the more complex levels of service provision.

Following the analytical scheme of Kazepov and Barberis (2013), this article examines the transformations of the social assistance policy both in its vertical dimension, territorial reorganization of regulation, and in its horizontal dimension, the interaction of a growing number of diversified actors. In what concerns the vertical dimension, we analyze the effects of federal normative acts and the structure of incentives and constraints defined by SUAS on the municipal level. Regarding the horizontal dimension, we investigate the interaction between state and non-state actors in São Paulo and the local political dynamics.

The study is based on the examination of secondary data and on 12 interviews carried out with relevant actors, such as high-level bureaucrats from the Municipal Secretary for Social Assistance and Development (SMADS), representatives from CSOs and from the Municipal Council of Social Assistance (COMAS).

\section{Implementing social policy in federal contexts: multi-level governance challenges}

"Where you live makes a difference, and the rescaling process that welfare regimes are undergoing increasingly constrains and enables individuals and families' agency according to the qualities of decommodified services they can have access to at the local level" (KAZEPOV, 2005, p. 24).

Kazepov's statement highlights the importance of analyzing the transformations in social protection systems at the local level. Following Madama (2013), we emphasize

4 These are private non-profit organizations. As stated by the national regulation, social assistance CSOs are organized according to the following parameters: execute regular activities; provide services and programs without charging the beneficiaries; enroll the beneficiaries in participatory processes.

(2017) $11(2) \quad$ - 
that the analysis should focus not only on policies such as pension systems or health care, but also on a relative 'marginal theme' in the comparative literature on the welfare state, which is the case of social assistance policies and their role in broader social protection systems.

At the local level, we can observe specific contentions around the provision and the regulation of policies and regarding the occupation of certain arenas by public and private actors. These disputes cannot be seen as the direct translation of national processes, even when there is a centralized decision-making process at the federal level. Instead, the analysis of these dynamics has to focus on the combination between central regulation and local decision-making autonomy, while considering the specificities of each context (KAZEPOV and BARBERIS, 2013; SELLERS and LINDSTRÖM, 2007).

In this article, we argue that the analysis of municipal dynamics is becoming more important to understand the governance of social assistance policies, even in a context of great centralization of decision-making power at the federal level, as argued by Arretche (2012). In the Brazilian federation, municipalities have political and administrative autonomy. However, the implementation of national policies increasingly depends on the national government's capacity of coordinating the instruments that are available to stimulate subnational governments to follow policy guidelines (ARRETCHE, 2012; BICHIR, 2011). Departing from the works of Rodden (2005) and Falleti (2006), Arretche (2012) makes a significant contribution by showing that it is not possible to conceive the decentralization of policy-making as equivalent to policy decision-making autonomy. Arretche (2012) found that, contrary to 'conventional wisdom', the Brazilian federation is quite centralized, since the national level has several institutional mechanisms that reinforce its authority vis-à-vis the states and the municipalities, like exclusive legislative authority regarding numerous issues, regulatory power, capacity to control the public spending of subnational governments, etc. (ARRETCHE, 2012).

Although we agree with Arretche's main arguments (2012), it is possible to observe an analytical tension regarding the distinction between policy-making and policy decision-making, especially if we consider that implementation may be a process full of decisions. We argue that it is important to follow Gomes's (2010) suggestion to investigate the decision-making autonomy of subnational governments in a systematic way. Thus, even in the case of federal regulated policies, it is important to understand the local dynamics of governance in a historical perspective, tracing the local balance 
between the capacities and constraints and focusing on different types of decisions taken at the municipal level.

The examination of a densely populated (11.2 million inhabitants), rich and unequal municipality such as São Paulo has both advantages and disadvantages. Even though comparisons are limited to similar metropolises, this case allows us to test the pertinence of arguments based on state capacities (BERSH, PRAÇA and TAYLOR, 20175; BICHIR, 2011, 2015; EVANS, 2011; SKOCPOL, 1985). On the one hand, it is necessary to have different types of resources-institutional, human, and financial, as well as public policy instruments able to reach the beneficiaries-to formulate and implement social policies. On the other hand, it is also necessary to consider ideas and disputes that define the mobilization and even the creation of state capacity in specific policy arenas, to combine both constraints and agency, moving beyond common criticisms to the first generation of historical neoinstitutionalism (MADAMA, 2013; REZENDE, 2012). Compared to other Brazilian municipalities, São Paulo has qualified human and financial resources (BICHIR, 2011). However, these resources are insufficient to guarantee the direct public provision of social assistance, and the dependency on CSOs to provide services is quite high. Besides the low relevance of this policy in the municipal agenda and the complexity of the vulnerable groups distributed across the territory, there are other restrictions defined at higher levels and beyond the social assistance policy governability, for example the Fiscal Responsibility Law, which sets limits to expenditures, especially regarding human resources expenses.

Regarding the social assistance policy, and specifically in the case of São Paulo, CSOs have historically played a central role, providing assistance services long before the 'idea' of social assistance as a 'public policy'—based on 'rights', and not on charitywas defined by the 1988 Federal Constitution. In this sense, we argue that it is also important to consider the organizational capabilities available for these CSOs, mainly: financial and human resources (including more flexible patterns of hiring than the public sector), fundraising ability, capacity to articulate with other actors and to

5 These authors emphasize the importance of analyzing bureaucratic capacity 'within' national bureaucracies, at the level of bureaucratic agencies, moving away from unitary concepts of state capacity. We agree with this perspective, and we complement it with two additional arguments: 01 . even in the same policy area agencies at the federal and at the municipal level may display very different capacities; 02. it is important to consider the balance between the capacities developed by state agencies and accumulated by non-state organizations enrolled in the policy process.

(2017) $11(2) \quad$ - $00003-5 / 28$ 
influence the policy, territorial reachability, and forms of accessing and interacting with the beneficiaries.

The autonomy/dependency relationship between state and non-state actors is influenced by the interaction of the different capacities mentioned above, and constrained by federal and municipal normative acts. It is therefore important to analyze the determinants of collaboration between state and non-state actors. Ansell and Gash (2007) identify the following dimensions: asymmetries in power relations, different capacities, background relations, and institutional constraints. As we will show, these elements are crucial to understand the local governance of social assistance in São Paulo.

Governance is a polysemous and controversial concept. Authors such as Lascoumes and Le Galès (2012) and Marques (2013) argue that this concept might prove useful in contexts in which the policy process involves state and non-state actors. In this article, we adopt Marques's definition of governance: "sets of state and non-state actors interconnected by formal and informal ties operating within the policy-making process and embedded in specific institutional settings" (MARQUES, 2013, p. 31). In our analysis, we move beyond normative perspectives and follow Lavalle and Szwako's (2015) claim that the state and civil society are 'mutually built', and thus have a relationship of co-determination.

Finally, it is important to consider the debate about regulation, which, as suggested by Kazepov (2005, p. 09), concerns the relations between different actors, the parameters for resources allocation and other forms of structuring conflicts. Furthermore, regulation involves commanding and controlling private provision of services and concerns the definition of parameters to structure these services (BALDWIN; CAVE and LODGE, 2012). In regards to the social assistance policy, it is essential to understand the national regulation of this policy-the definition of macro parameters-and the creation of specific normative acts at the municipal level.

\section{SUAS: a new paradigm with different translations}

Social assistance is a very old field of interventions in Brazil, historically organized by charity organizations in a very fragmented way, lacking the regularity and the minimal parameters that characterize a public policy. The 1988 Federal Constitution is a well-established milestone in the recognition of social assistance as a public policy, 
and as a part of the non-contributory social security system as well. The institutional transformation of this field started in the 1990s (ALMEIDA, 1995). Nevertheless, the building of a national system of social assistance, known as SUAS, has started only in the 2000s through the definition of national parameters for service provision. These national parameters include definition of rights, levels and types of social assistance protection, rules for federative co-funding, profiles of human resources and parameters for service provision, including not only rules for the direct administration but also for the CSOs enrolled in SUAS. The main principles of SUAS define social assistance as a universal and decentralized policy, based on social participation and on federative negotiation. There are great expectations about SUAS as a 'new paradigm' (COLIN; PEREIRA and GONELLI, 2013), despite the recognition of the tensions and disputes around this system (SPOSATI, 2009). These disputes tend to associate CSOs in service provision with a philanthropic past - the omnipresent idea of "charity legacy — that must be surpassed to guarantee social assistance as a public policy" (BRETTAS, 2016). As we argue in this article, this representation is imprecise and misleading, in particular vis-àvis the complex interconnections between different types of state and CSOs actors we have found in our fieldwork.

The general normative parameters, policy instruments and regulations of SUAS are defined at the federal level through a federative negotiation process with a very important role played by the Ministry of Social Development (MDS), and by the National Council of Social Assistance (CNAS). Based on these national parameters and on complementary locally-defined regulation, the municipalities oversee service and benefits provision. This implies an important level of decision making at the municipal level: identifying and addressing different types of social vulnerability in their territories to offer specific kinds of services. The principles of co-responsibility between all levels of the federation and the co-financing of actions and services, through transfers from the National Fund for Social Assistance to the municipal and state funds, contribute to the definition of the federative structure of the system. Each municipality must organize a council and a fund of social assistance and establish a plan of action to be part of SUAS. 
Public facilities ${ }^{6}$ and private non-profit organizations provide services and benefits at the municipal level, in different mixes of public-private cooperation.

One of the main ideas supported by experts and high-level bureaucrats is the need to guarantee the construction of a public policy based on citizenship rights and on the state's responsibility for social protection (COLIN; PEREIRA and GONELLI, 2013; JACCOUD; HADJAB and CHAIBUB, 2009). This idea is particularly relevant to leftist governments (ALMEIDA, 2004; SÁTYRO and CUNHA, 2014) that advocate for a more intense participation of the state not only in the regulation of CSOs, but also in the direct provision of services. Although the national normative acts on social assistance establish co-responsibility and complementary relations between state and non-state actors, these definitions are not consensual, and there are disputes concerning the meanings of 'state responsibility', 'co-responsibility' and the role of CSOs7. These disputes reflect not only different ideological perspectives regarding the state's role in this policy, but also the historical process of capacity building to service delivery, which, in the case of São Paulo, is mainly concentrated in some CSOs, and not inside the public sector. Contradicting some authors (AMÂNCIO, 2008; MARIN, 2012), we argue that this does not mean that SUAS is not being implemented in the city.

Overcoming the legacy of past practices also means to define minimum parameters for service provision. For a long time, the debates within the policy community focused on defining what was not part of social assistance policy . A positive agenda was only recently established through some normative acts such as the national parameters for service provision in 2009 and through the definition of types of social protection. Social assistance's blurred boundaries and complex concepts (such as 'vulnerability') sometimes harm the external recognition of its relevance as social policy. Throughout the processes of formulation and implementation of SUAS, it is possible to observe the (inter)action of numerous actors, such as activists and members of the

6 There are two main types of public facilities: 01. Social Assistance Reference Centers (CRAS) deliver basic social protection; 02. Specialized Social Assistance Reference Centers (CREAS) deliver high complex social assistance services.

7 Analyzing the interactions and disputes between state and non-state actors around the national regulation of the social assistance policy, Brettas (2016) identifies three main phases: 01. a state-centered approach after 2004, which emphasized state action both in the regulation and in the service provision; 02. after 2010, a new conception of 'SUAS private social assistance network'; 03. around 2013, the idea of 'private network' lost space to the centrality of the idea of a 'single' social assistance network of service provision, with public purpose, regardless of the nature of the organization providing the services. 
academia with connections to the social assistance community (ABERS; SERAFIM and TATAGIBA, 2014) and closely linked to leftist movements and parties (GUTIERRES, 2015) and CSOs (BRETTAS, 2016). Moreover, as we found in the city of São Paulo, connections between bureaucrats located at different levels are very important to discuss the possible translations of SUAS into concrete services, programs and regulations. During some administrations, the city conducted pioneering practices regarding service provision that later were incorporated into SUAS, in a process of policy experimentation also seen in other metropolises (GUTIERRES, 2015; MARIN, 2012).

What does it mean to 'implement' the SUAS in very heterogeneous municipalities? Many authors recognize that translating the idea of social assistance as public policy into concrete actions is not a simple task, especially in the case of service provision. Silva et al. (2012) highlight the following explanatory dimensions: lack of municipal resources to fund the services; difficulties in the structuring and planning of the services offered in public facilities; normative acts that allow greater room for improvisation and intuitive adaptations in facilities, with different consequences; and low capacity of service delivery in public facilities, especially in the face of specific demands and vulnerabilities.

Metropolises have comparative advantages and disadvantages in the implementation of the national policy of social assistance, and many bureaucrats complain about the mismatch between the federal parameters and their realities, since most of the time the national parameters are focusing on the reality for the majority of the cities, i.e., small-scale cities, with less than 50 thousand inhabitants ${ }^{8}$. The most populated cities have higher institutional capacities when compared to smaller ones (BICHIR, 2011), which translates into having secretariats exclusively for social assistance, specific municipal regulation for the area, human resources that are comparatively more qualified, larger infrastructure, information systems, etc. Yazbek et al. (2012) recognize that the argument of institutional capacities does not explain this phenomenon on its own, and suggest that political decisions taken at the municipal level are central to explain these differences. They also argue that the existence of political

8 In 2013, a national pact for improving the social assistance implementation in the country recognized specific parameters and goals for metropolises. 
agreements between the three levels of the bureaucracy and social assistance organizations is an important explanatory factor.

What does it mean to implement SUAS in São Paulo? The trajectory of social assistance in the city is punctuated by moments in which it becomes estranged from the federal guidelines and by moments of groundbreaking initiatives. Historically, the provision of social assistance in São Paulo was characterized by the fragmentation of actions and by the dependency on CSOs, since the involvement of the state is considered weak both in what regards service provision and regulation (AMÂNCIO, 2008; CARDOSO, 2003; MARIN, 2012; YAZBEK, 2004). Despite not having specific training on the subject, first ladies, i.e., mayors' wives, were traditionally in charge of this policy. Institutional venues such as the Municipal Council for Social Assistance (COMAS) ${ }^{9}$ and the Municipal Fund for Social Assistance (FMAS) only started to function during the leftwing administration of Marta Suplicy (2001-2004), who was, not coincidentally, the first to appoint an expert in social assistance to lead the municipal secretariat of social assistance.

There are some explanations for the advances and setbacks in the municipal trajectory of social assistance. According to Marin (2012), this configuration is due to: 01 . the rotation between progressive administrations, which understand social assistance as a right and a public policy, and conservative administrations that associate the field with charity, focusing on discontinuous and discretionary actions; and 02. the existence of moments of alignment with the federal level punctuated by moments of estrangement. We argue that these arguments alone do not explain the modes of governance of the social assistance municipal policy, particularly those of the Haddad administration (2013-2016), which is politically in line with the federal administration ${ }^{10}$. We also consider the argument of Amâncio (2008) to be an insufficient explanation: the author contends that the municipal policy is guided by micro-decisions that are made at the local level, mainly by CSOs, more than it is guided by the state's rationality (macro-decisions). From our point of view, this is an oversimplified vision of the policy that does not give enough attention to the complexity of multi-level governance.

9 The Municipal Council of Social Assistance (COMAS) was created in 1997, during the conservative administration of Celso Pitta (1997-2000).

10 Until Dilma was stripped of her presidential duties in May 2016, after the lower chamber voted to begin an impeachment trial. 
Yazbek et al. (2012) have identified another explanatory element; the secretary's profile. The authors emphasize the importance of having secretariats that combine technical and political elements. In addition, we argue that it is crucial for the head of the secretariat to belong to or be connected with the social assistance policy community. This relational resource is important to navigate through the ideas and normative parameters, since the secretary is the first level of local transformation of the federal laws into specific municipal regulations, and to be able to pull the strings in the interaction with the CSOs, which dispute ideas and definitions inside this policy community, even at the federal level. This relational resource of the head of the secretariat also translates into a higher capacity of bargaining, which is especially important in the interactions with the CSOs; knowing the terminology, the disputes around the identity of social assistance, the legacy, and the numerous and sometimes confusing normative acts regarding this policy sector, matters.

In this article, we argue that the social assistance municipal dynamics do not directly reflect the national parameters, since there is relative space for municipal translations and adaptations considering local dimensions of vulnerability, local institutional capacities and the decisions taken in the interaction between state actors and CSOs. First, the national policy of social assistance only defines general parameters, allowing for local adaptations and for the formulation of municipal normative acts. The social assistance services in many municipalities have been in place long before the idea of social assistance as a public policy, and there is a complex negotiation in this adaptation to SUAS's definitions. Secondly, São Paulo is comparatively well-resourced, which means that the city has more autonomy and more capacity to make choices than most municipalities. However, São Paulo faces very specific challenges because of the high social and spatial heterogeneity of the vulnerable groups. To understand how national parameters and regulation affect the relations between state and non-state actors in social assistance service provision, it is necessary to consider local legacies, the place of social assistance in the municipal political agenda and budget, the political and ideological orientation of the municipal administration, the social assistance secretary's profile, and the interactions with CSOs in arenas such as COMAS. 'Following SUAS' may have different local translations, as we discuss in the following section. 


\section{Implementing SUAS in São Paulo: historical legacies and recent trends}

"Social assistance in São Paulo is the CSOs"11. "Today the CSOs are part of social assistance. Before, they were the social assistance"12.

\section{General patterns and institutional arenas}

Currently, 94\% of the agents supplying social assistance services in São Paulo are CSOs that have signed a partnership with the municipality ${ }^{13}$. Although there is an important variation across the country, the national data points to a very different scenario: on average, $68 \%$ of the social assistance units are public and only $32 \%$ are private (BRASIL, 2015). This means that, in São Paulo, the public sector is much more enrolled in the regulation and supervision of the services offered by these private nonprofit organizations, and not in the direct provision of services. São Paulo's huge dependency on CSOs was built over time, through the action of different types of organizations, some of them related to religious associations, others with grassroots movements and neighborhood associations in charge of service provision (AMÂNCIO, SERAFIM and DOWBOR, 2011; LAVALLE, CASTELLO and BICHIR, 2008).

Considering the main institutional arenas, the municipal secretariat, SMADS, oversees the social assistance policy in the city. This secretariat is responsible for adapting the federal normative regulation to the local reality, as well as to develop municipal guidelines for social assistance and for the payment and regulation of CSOs enrolled in service provision. The regulation and supervision of CSOs' legal reports and accountability also occurs through decentralized structures closer to the neighborhoods, following the principle of policy territoriality. Public facilities in charge of basic service provision-Reference Center for Social Assistance (CRAS) and for more complex service provision-Specialized Reference Center for Social Assistance (CREAS) are also in charge of service provision at basic and complex levels, respectively, relying on a team of public social workers, psychologists and other professionals. The policy arrangement

\footnotetext{
11 Interview with a high-level bureaucrat of SMADS.

12 Interview with the head of the municipal secretariat.

13 These numbers are valid for the basic social assistance services. When it comes to specialized social assistance services, CSOs are responsible for the totality of their provision in the city (BRASIL, 2015).
}

(2017) $11(2) \quad$ - e0003-12/28


comprises relevant arenas for the interaction between state and civil society actors, such as the Municipal Forum for Social Assistance (FAS) and COMAS.

FAS primarily consists of beneficiaries, social assistance workers and organizations that operate in the field. Due to its trajectory and its precedents, the forum has been recognized as a 'stronghold'14 of social assistance's interests, even during the conservative administrations prior to the implementation of SUAS (YAZBEK, 2004). COMAS, on the other side, is a collegiate body with deliberative, legislative and monitoring prerogatives, composed of an equal number of members from government and civil society. Tatagiba (2007) shows that COMAS is an influential actor both in the formulation and in the implementation of the social assistance policy. The registration of social assistance organizations in this council is the starting point to establish a partnership with the public sector. This council has the prerogative to approve (or not) the government's program for social assistance, which is developed by the municipal secretariat. Our interviews also reinforce the idea of COMAS as an important arena to defend the CSO's interests; 'the organizations are there and have the strongest voice' 15 . However, not all CSOs are capable of gaining access to COMAS and making an appropriate use of it. Small CSOs often depend on the most powerful organizations to be able to participate in the council.

COMAS also plays a major role in what concerns the budget, lobbying for increases of funding in the municipal chamber (TATAGIBA, 2007). Peres ${ }^{16}$ (2016) stresses the existence of different levels of conflict in the municipal budgetary process, whose definition is, in part, a result of the federal structure associated with the funding of SUAS. The share allocated to social assistance within the municipal budget is constrained due to federal-set mandatory expenses, such as expenses with personnel (active and inactive), as well as other incompressible expenditures, such as the federalset earmarking expenses with health and education (PERES, 2016). Additionally, the share of social assistance in the budget reflects how important this policy area is in the mayor's agenda, as well as the interactions between the municipal chamber, the CSOs

\footnotetext{
${ }^{14}$ Interview with a CSO's representative.

15 Interview with a representative from the public sector within COMAS.

${ }^{16}$ We would like to thank Ursula Peres for the valuable explanations regarding the municipal budget process and for assisting us with data collection and treatment.
} 
and the COMAS to define supplementary resources. Most of the times, even in left-wing administrations, social assistance is not a priority policy area.

São Paulo's social assistance budget is composed of a relatively small contribution from the federal government, similar to that provided by the state government, and of a huge amount of municipal resources. Between 2013 and 2015, the municipal treasury was responsible for $85 \%$ of the funding of social assistance in the city of São Paulo (Graph 01). During this period, the amount transferred by the federal government increased, but it only corresponds to $06 \%$ of the total funding, the State of São Paulo being responsible for the transfer of another $06 \%$ of the total budget. This is quite a different pattern from what we observe in other Brazilian municipalities: in general, the municipal and the federal governments are responsible for a huge part of the budget, while states make very small contributions (SILVA et al., 2012). This does not mean, however, that the federal resources are irrelevant, as emphasized by the current head of the secretariat: 'we cannot afford to lose these resources'.

Graph 01. Social assistance budget (2013-2015)

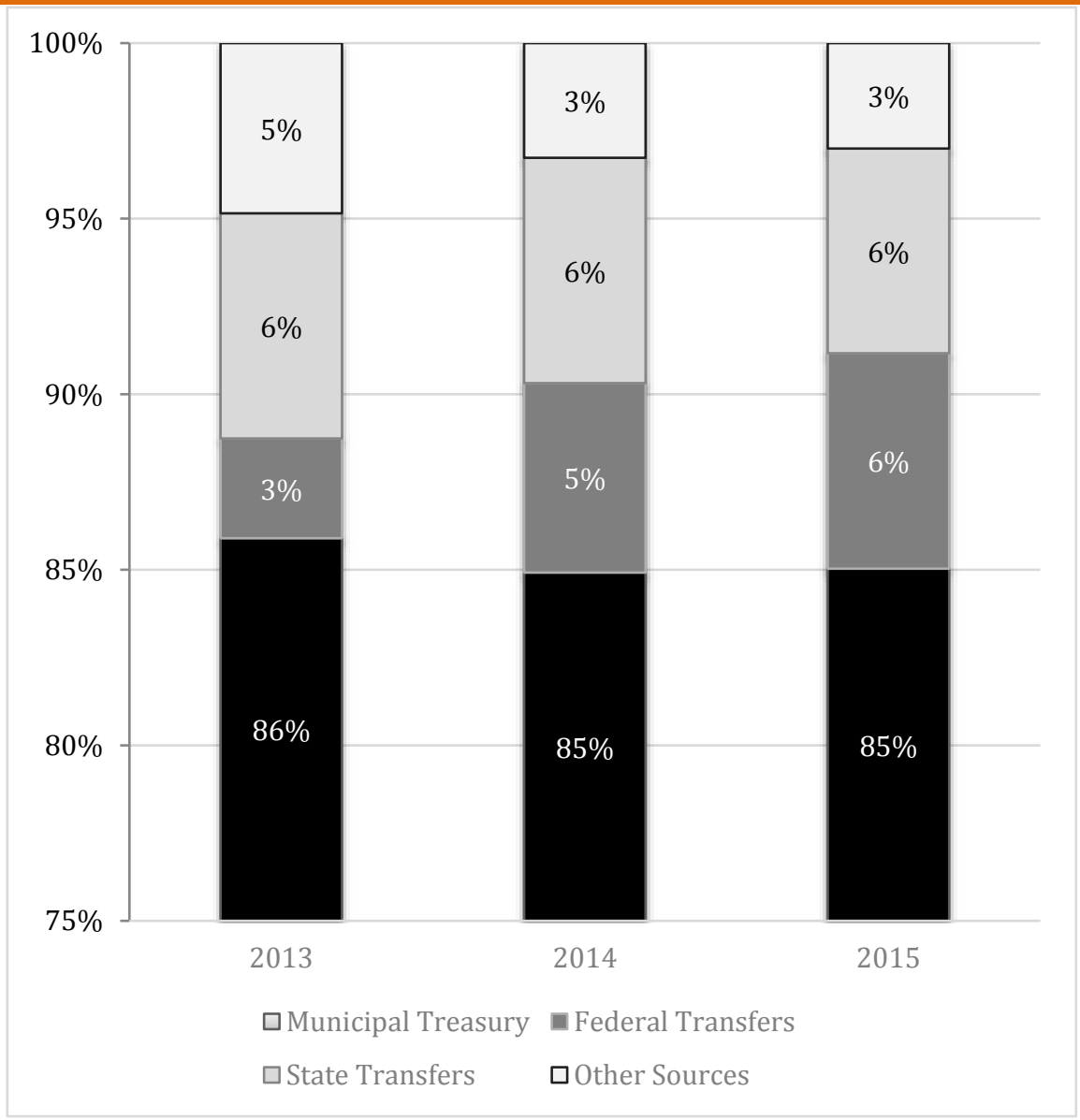

Source: Municipal Secretariat of Finances, Municipal Budget Execution, 2013-2015. 
When we compare the share of social assistance with other sectorial policies, it becomes apparent that it is still seen as a secondary policy. Between 2013 and 2015, only $02 \%$ of the municipal budget was allocated to social assistance (with a fall in real terms, due to inflation). Besides, different interviewees stated that municipal actors loosely employ the resources of social assistance in a great variety of actions and programs, not necessarily connected with its core aims. In this sense, the vague definition of this policy and the disputes around its objectives have not only ideological consequences, but also budgetary ones.

The CSOs that participate in these arenas and compete for funding are very diverse in terms of their financial, political and lobbying resources. While some of the CSOs are linked to religious and philanthropic organizations, others have their roots in social movements. There is also a great variation regarding size and forms of organization. There are small organizations whose activities are restricted to a specific territory, whereas others function as if they were companies, providing different services in diverse areas of the city. The number and profile of beneficiaries also varies greatly, which affects the CSO's bargaining power with the public sector: the larger the share of demand one civil organization is responsible for, the bigger its power; this is also valid for organizations specialized in serving specific vulnerable groups. Regarding budget, the CSOs vary according to the level of their dependence on partnerships with the public sector or availability of alternative sources. Another important characteristic concerns the period in which CSOs started to participate in the municipal policy-before or after the implementation of SUAS. Those CSOs that were already participating in the policy tend to be more resistant to change; it is more difficult for them to adapt to the parameters of SUAS. Finally, it is also possible to differentiate those CSOs whose activities are mainly or exclusively in the field of social assistance, and those who develop activities in other areas. In the first case, they tend to adhere to the social assistance policy more than in the second case. These characteristics imply different relations amongst the organizations and different resources in the interaction with the public sector.

This article follows the debate around the importance of understanding the modus operandi of CSOs, an idea present in the work of Lavalle, Castello and Bichir (2007): "the relational approach shows that-at least in the case of São Paulo-the universe of civil society organizations is hierarchical and unequal in what concerns the 
capacity to act and to dialogue" (LAVALLE, CASTELLO and BICHIR, 2007, p. 488). In an analysis about the specific patterns of relationships between the social assistance organizations among themselves and with other civil society actors, Lavalle, Castello and Bichir (2008) state that these organizations are connecting peripheral organizations, such as neighborhood associations, to financial organizations, acting like mediators.

We have also found an interesting pattern of hierarchical relations and of specialization. Our interviews suggest that CSOs' actions are not fragmented, as argued by Amâncio, Serafim and Dowbor (2011). Quite the contrary: the existence of an organized group of CSOs aiming to advocate their agendas strengthens their organizational capacities. Our results point to the existence of specific forms of articulation: large organizations tend to easily access the institutional arenas (COMAS, FAS and SMADS) and can influence the disputes, while small associations tend to gather around big organizations and help to put pressure on certain topics and support specific positions.

Big organizations, both religious and non-religious, have a central role in service supply, participate actively in COMAS and FAS, are capable of bargaining, and are less dependent on public resources, since they have other sources of funding. They can improve their employees' wages and to offer more diversified services, beyond the minimum parameters defined at national and municipal levels. In some cases, they act as if they were an extension of the municipality and they conceive their service provision as public. It is then possible to affirm that the public sector is seriously dependent on these organizations, especially upon a couple of large organizations that were frequently mentioned in our interviews, but also dependent on the small-scale ones, which have great territorial reachability and can reach specific vulnerable groups. This does not mean that the state is not trying to improve its capacity for service provision, as discussed in the next section.

\section{State capacity in service provision: the public facilities}

A central dimension to ensure the implementation of SUAS is the expansion of social assistance public facilities, and this has happened in São Paulo. Departing from the analysis of the expansion of public facilities for the provision of basic social assistance 
(CRAS) during the period of 2010-201417, we can affirm that the most expansion has occurred in the small municipalities of the southeast and northeast regions. If we look at the CRAS relative growth rate per state, São Paulo differs from the rest. The state is considered to be a latecomer in the implementation of SUAS, but in the recent years its growth rate is the third highest in the country (while the national average is 19\%, São Paulo's growth rate is $33.46 \%$ ), which indicates that efforts to converge with the national policy are under way. When we compare the expansion in the City of São Paulo to the State of São Paulo and other metropolises, the City of São Paulo stands out (Graph 02).

Graph 02. CRAS Expansion, 2010-2014

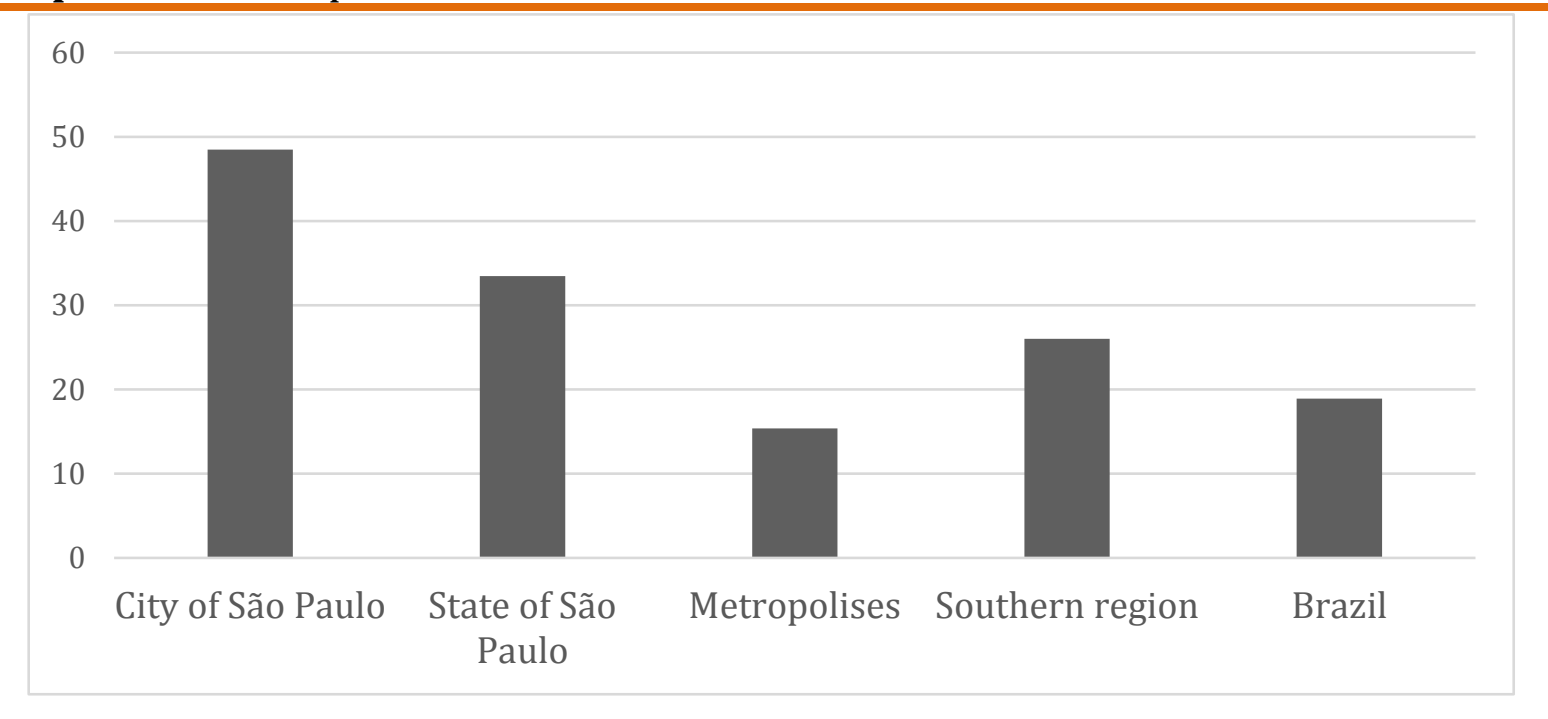

Source: Censo SUAS.

Table 01. Number of Basic public facilities (CRAS), 2010-2014

\begin{tabular}{lccccc}
\hline & 2010 & 2011 & 2012 & 2013 & 2014 \\
\hline City of São Paulo & 33 & 44 & 48 & 49 & 49 \\
State of São Paulo & 783 & 908 & 951 & 976 & 1045 \\
Metropolises & 351 & 380 & 392 & 392 & 405 \\
Southeast region & 2194 & 2466 & 2577 & 2643 & 2765 \\
Brazil & 6801 & 7475 & 7725 & 7864 & 8088 \\
\hline
\end{tabular}

Source: Censo SUAS.

17 We would like to thank José Militão for the processing of data from Censo Suas, which served as a basis for the elaboration of the maps, tables and graphs used in this section.

$$
\text { (2017) } 11(2) \quad \text { e0003-17/28 }
$$


Nevertheless, it is important to mention that the number of CRAS in the City of São Paulo (Table 01) is still much lower than what we would expect from the observation of the national parameters ${ }^{18}$. Building 60 new CRAS was one of the goals of Haddad's administration for social assistance, but in 2016 only five new CRAS were ready. Expanding public facilities may even be a political goal, but there are several barriers to this expansion, especially constraints on hiring staff. This leads to greater dependency on the services provided by CSOs.

\section{Local politics and disputes around normative acts}

"It is necessary to define parameters, but the ones that already exist are very distant from São Paulo's reality"19.

A central issue to the transformation of the social assistance into a social policy and to overcome a legacy of fragmented actions is the definition of minimum parameters for service provision, including types of services, profile of the human resources (number of professionals for each service and their qualifications), and regulation of the CSOs. The relevance of the regulation of this policy field is not only explained by rightwing versus left-wing administrations-politics go beyond that. A central dimension in this case is the profile of the head of the secretariat, his/her goals and agendas and connections to the policy community and with the CSOs in relevant arenas. Additionally, local decisions also aim to deal with specific metropolitan challenges, and the federal regulation often does not offer support for this.

The first municipal efforts regarding minimum parameters for service provision and CSOs regulation started before SUAS was set at the national level, during the leftwing administration of Marta Suplicy (2001-2004), from PT (Workers' Party) at that time. As head of the social assistance secretariat (2002-2004), Aldaíza Sposati implemented actions later considered as a 'laboratory for SUAS' (Gutierres, 2015). She worked to create a municipal legislation to organize the relations between the city and CSOs, and to foster the dialogue with CSOs within arenas such as COMAS. Together with the CSOs, this administration organized a study on the costs of each service, and tried to

${ }^{18}$ The goal is to have one CRAS for each group of five thousand vulnerable families registered.

19 Interview with a representative of SMADS.

(2017) 11 (2) = [ e0003-18/28


define minimum parameters regarding human resources profiles, costs and qualification. Later, these were central dimensions in the national policy. Some actors related to the civil society still complain about the centralized profile of this administration ('the public sector defined [the rules], and they had to adapt'20), while others characterize Sposati (2009) as an 'enemy of CSOs', due to her strong emphasis on state responsibility in this policy field. Consequently, the CSOs' role in service provision was characterized as a type of 'outsourcing' of the state's activities, an idea that still remains strong amongst this policy community and that influences social workers in charge of supervising CSOs' activities even today ${ }^{21}$.

In 2005, during the centrist administration of José Serra (2005-2006) and while Floriano Pesaro (2005-2008), a sociologist from the same party (Brazilian Social Democracy Party, PSDB), was head of the social assistance secretariat, São Paulo formally adhered to SUAS. There were contradictory movements during this period: after 2007, the city went through a restructuring process to adapt to SUAS, while implementing local social assistance programs aiming to develop a 'municipal brand' in the area of social assistance (Marin, 2012). Interested in leaving a 'personal mark', Pesaro tried to impose his own agenda, not following the federal guidelines for basic service provision and managing to obtain support from the CSOs, especially within FAS.

After Pesaro left the secretariat to run for the municipal chamber, the right-wing administration of Gilberto Kassab (2006-2012, at that time from Democrats Party (DEM) nominated the vice-mayor Alda Marco Antonio, who was affiliated to the Brazilian Democratic Movement Party (PMDB) and an engineer with previous experience in the field of social assistance, as secretary (2009-2012). At that period, the national policy of social assistance was more consolidated-largely due to the visibility of the 'Bolsa Família' program (BICHIR, 2011, 2016a, 2016b)-and the municipal secretary finally started 'following the SUAS', although with a very different interpretation from that of Sposati (2009) in what concerns the role of the state and of CSOs in this field. Alda was responsible for expanding the number of CRAS and expanding the partnerships with CSOs; many of these organizations were created during this administration. Two of the most-important municipal normative acts were

\footnotetext{
${ }^{20}$ Interview with middle-level bureaucrat.

21 This idea circulates not only in the formation of social workers - and the Catholic University of São Paulo (PUC-SP), where Sposati is a professor, is one of the major references in this field - but also inside the social workers' union, according to our interviews.
} 
developed in this administration: one regarding the municipal parameters for social assistance and the regulation of partnerships based on agreements, and other concerning the reference cost of social assistance services provided by partner organizations. These municipal regulations were discussed 'pari passu' with the national regulations, and cross-learnings happened due to the connections between middle-level bureaucrats in the municipality and high-level bureaucrats from MDS, who were debating the national classification of services ${ }^{22}$. In this sense, the implementation of some of SUAS' leading ideas depends not only on the head of the secretariat, but also on the permanent bureaucracy.

The connections to the social assistance policy community proved once again to be important, particularly in what concerns the development of normative acts and legislation aiming to regulate the relations with CSOs. As mentioned by some of our interviewees, this was made possible because of Aldaíza and Alda's capacity to mobilize different resources; political capital, knowledge of SUAS' normative acts, and the ability to connect with different actors within the social assistance field not only at the municipal level, but also nationally.

The administration of Fernando Haddad (2013-2016), affiliated with PT, continued the recent trend of nominating secretaries with a technical and political profile. However, his secretary, Luciana Temer, was not a member of the social assistance community, but a lawyer affiliated with the centrist PMDB. Her appointment as the secretary was driven by the logic of government composition and by her political capital; she is the daughter of Michel Temer, the current president after Dilma Roussef's deposition. There are advantages and disadvantages associated with the estrangement of the secretary from the field of social assistance. The secretary put forward new agendas and innovations, a behavior that suggests that she was less influenced by the legacy of this policy or by strict definitions of what should be considered as social assistance. On the other hand, as there was a huge asymmetry of information between the secretary, SMADS's bureaucrats and CSOs that have signed agreements with the secretariat. Luciana Temer's administration

\footnotetext{
22 These bureaucrats were part of the same political group inside the policy community, closer to Sposati (2009) and her vision of state responsibility and CSOs control. This finding reinforces the relevance of the connections and circulation among social movements and bureaucracies for the diffusion of certain ideas, as pointed out by Abers, Serafim and Tatagiba (2014).
} 
sought to improve some of the previous normative acts, in a more democratic perspective. One of the priorities, regarding regulation, was the definition of a protocol for the supervision of CSOs, aiming to minimize discretionary decisions in this activity.

The members of the CSOs we have interviewed have more often mentioned the municipal normative acts than the federal ones. These mentions are frequently associated with complaints about the existence of 'too many parameters'23 and about their rigidity, and with criticisms regarding the low values that serve as reference costs. It is also common to hear that these normative acts leave a huge margin to interpretation in the supervision of CSOs' reports. The discretionary interpretation of the normative acts is a constant object of conflict between CSOs and the municipal secretariat, especially regarding the space for discretionary interpretations by middlelevel bureaucracy when the secretary is alien to the social assistance community. The larger CSOs are familiarized with these normative acts and regulations. As one of our interviewees said, 'knowing how to interpret the text is everything'. The secretary's profile, in right-wing or left-wing administrations, and his/her knowledge of the field might facilitate (or not) the dialogue between the public sector and the CSOs. Many of the normative acts have been developed within COMAS, where the major CSOs are highly-powerful actors in the negotiations. Our data supports Yazbek et al.'s (2012) argument about the organizations' autonomy in the city of São Paulo, despite the existence of legal constraints and minimal standards defined by the public sector to regulate CSOs' actions, they enjoy great technical and managerial autonomy.

Briefly, in the case of São Paulo, the interplay between federal and municipal normative acts is constrained by historical legacies - the resilience and expansion of CSOs' service provision-by the profile and agendas of the head of the secretariat and her/his connections with the social assistance policy community. If the federal funding seems relatively small, when considered in absolute values, it is a considerable amount, pushing for the idea of following the SUAS (otherwise, the transfer of federal resources may be interrupted). Sometimes the national parameters are very different from the city's reality. Thus, the space for local disputes over regulation is even bigger, and the

23 Interview with a CSO's representative. 
results depend on the balance of forces between the head of the secretariat and her/his staff with the CSOs in the main arenas of this policy.

\section{Conclusions}

This article sought to analyze the determinants of the implementation of the municipal policy of social assistance in São Paulo, in the light of the constraints and incentives arising from vertical relations, and in particular those defined by SUAS. Another goal was to examine these determinants departing from the observation of horizontal governance dynamics, focusing on the relationship between state actors and CSOs involved in the provision of social assistance services. We showed that macroexplanations and broad categories are not sufficient to explain the municipal governance patterns; there are different dynamics in right and left wing administrations, but local politics go beyond that. We also demonstrated the diversity of profiles, ways of interaction and resources of CSOs that participate in the social assistance policy in São Paulo. Finally, we have presented the complexity of state and non-state actors' interactions in the policy process.

Even in the context of a national system of social assistance, with a certain level of centralized decision-making, local decisions matter when implementation takes place, especially in the case of a 'strong local power' (SELLERS and LINDSTROM, 2007), such as São Paulo. This autonomy implies the absence of complete adherence to the national agenda, even when the mayor and the president are politically aligned, that is, are affiliated to the same party or political coalition. To understand the patterns of governance in this field, it is important to know the disputes and local political dynamics.

In what concerns the vertical relations, São Paulo has some decision-making autonomy partly because of its institutional capacities (BICHIR, 2011; SELLERS and LINDSTROM, 2007). However, this argument is insufficient to explain the policy dynamics. This is a municipality with high capacities (administrative and financial resources, recent expansion of public facilities) and a certain degree of autonomy. The forms of policy governance differ from what is stipulated at the national level. While one of the central principles of SUAS is the centrality of the state not only in the regulation of private organizations, but also in the direct provision of services, São Paulo is still highly dependent on the CSOs' provision. Besides, organizations also play a major role in the 
definition and interpretation of normative acts. As we have shown, the key disputes at the municipal level are related to the municipal budget and the amounts payed to the CSOs, and over the definition of minimal principles regarding service provision.

Thus, political choices, constraints and local dynamics matter. At the federal level, a link between more progressive governments and agendas that favor the state provision of services has been identified, particularly when we compare Fernando Henrique Cardoso and Lula's administrations (ALMEIDA, 2004; SÁTYRO and CUNHA, 2014). However, in the case of São Paulo, it is not possible to make such a direct association. The differences between Marta and Haddad's administrations (both from the Workers' Party, PT, at that time) suggest that besides the mayor's political and ideological profile, it is also important to consider the political and ideological orientation of the secretary of social assistance. In addition to the technical and political requirements, being part of the social assistance community makes a difference, especially in what concerns the relationship with CSOs; variation in the capacity of putting agendas forward, active/reactive attitude in face of the CSOs' demands, and (as)symmetry of information.

Certain arenas are essential to foster the interaction between state and nonstate actors and to the construction of the municipal policy. These disputes happen within formal institutions, such as COMAS, SMADS and the municipal chamber, but also in informal ways. There is a CSO ecology, a myriad of organizations interacting and disputing the decision-making arenas. These dynamics are influenced by different determinants that may be combined in different ways. So far, it is possible to highlight the following aspects: size of the organizations (budget, sources of resources and services capacity); time of creation or expansion (before or after SUAS implementation); origin and profile (within social movements, religious organizations or managerial profiles); and fields of action (social assistance only or also in other areas).

Departing from the data that we have analyzed so far, we can argue that the local governance of the social assistance policy is defined by the capacities (municipal budget, human resources, well-defined institutional arenas) and by the constraints (size, profile and spatial distribution of the vulnerable population, the low budget and scarce attention paid to this field) that characterize this policy. Moreover, these governance patterns are explained by the choices and the contingent results arising from the complex formal and informal interactions between state and non-state actors, which 
follow rules and different dynamics in distinct levels of governance, ranging from the minimal parameters defined at the national level in the frame of SUAS to norms defined at the municipal level.

Revised by Lindsey Silva Submitted on August 26, 2016 Accepted on January 11, 2017

\section{References}

ABERS, Rebecca.; SERAFIM, Lizandra, and TATAGIBA, Luciana (2014), Repertórios de interação estado-sociedade em um estado heterogêneo: a experiência na era Lula. DADOS. Vol. 57, № 02, p. 325-357.

ALMEIDA, Maria Hermínia Tavares de (2004), A políticas social no governo Lula. Novos Estudos CEBRAP. № 70, pp. 07-17.

ALMEIDA, Maria Hermínia Tavares de (1995), Federalismo e políticas sociais. Revista Brasileira de Ciências Sociais. Vol. 28, № 10, pp. 88-108.

AMÂNCIO, Júlia Moretto (2008), Parcerias entre Estado e sociedade civil: significados e desafios na gestão de políticas públicas. 0 caso da assistência social em São Paulo. Master dissertation. Instituto de Filosofia e Ciências Humanas. Universidade Estadual de Campinas.

AMÂNCIO, Júlia Moretto; SERAFIM, Lizandra, and DOWBOR, Monika (2011), Microterritorialidade e controle societal. Lua Nova. № 84, pp. 353-364.

ANSELL, Chris and GASH, Alison (2007), Collaborative governance in theory and practice. Journal of Public Administration Research and Theory. Vol. 18, pp. 543-571.

ARRETCHE, Marta T. S. (2012), Democracia, federalismo e centralização no Brasil. Rio de Janeiro: Editora Fiocruz. 232 pp..

BALDWIN, Robert; CAVE, Martin, and LODGE, Martin (2012), Understanding regulation. Oxford: Oxford University Press. 568 pp..

BERSCH, Katherine; PRAÇA, Sérgio, and TAYLOR, Matthew M. (2017), Bureaucratic capacity and political autonomy within national states: mapping the archipelago of excellence in Brazil. In: States in the developing world. Edited by CENTENO, Miguel A.; KOHLI, Atul and YASHAR, Debora J.. Cambridge: Cambridge University Press. pp. 157-183.

BICHIR, Renata Mirandola (2016a), Novas agendas, novos desafios: reflexões sobre as relações entre transferência de renda e assistência social no Brasil. Novos Estudos CEBRAP. Vol. 35, № 01, pp. 104-137. 
BICHIR, Renata Mirandola (2016b), Descentralização político-administrativa. In: Dicionário crítico: política de assistência social do Brasil. Edited by FERNANDES, Rosa M. C. and HELMANN, Aline. Porto Alegre: Ed. da UFRGS. pp. 69-73.

BICHIR, Renata Mirandola (2015), Capacidades estatais para a implementação de programas de transferência de renda: os casos de Brasil, Argentina e África do Sul. Texto para Discussão. IPEA, № 2032.

BICHIR, Renata Mirandola (2011), Mecanismos federais de coordenação de políticas sociais e capacidades institucionais locais: o caso do Programa Bolsa Família. Rio de Janeiro. PhD dissertation. Instituto de Estudos Sociais e Políticos. Universidade Estadual do Rio de Janeiro.

BRASIL, Ministério do Desenvolvimento Social e Combate à Fome (2015), Censo SUAS 2014: análise dos componentes sistêmicos da política nacional de assistência social. Brasília, DF: MDS, Secretaria de Avaliação e Gestão da Informação. Secretaria Nacional de Assistência Social. 176 pp..

BRETTAS, Gabriela Horesh (2016), O papel das organizações da sociedade civil na política pública de assistência social no Brasil: dilemas e tensões na provisão de serviços. Master dissertation. Gestão de Políticas Públicas. Escola de Artes, Ciências e Humanidades. Universidade de São Paulo.

CARDOSO, Priscila (2003), Fundo municipal de assistência social da cidade de São Paulo. Observatório dos direitos do cidadão: acompanhamento e análise das políticas públicas da cidade de São Paulo. São Paulo: Instituto Pólis/PUC-SP. 64 pp..

COLIN, Denise Ratmann Arruda; PEREIRA, Juliana Maria Fernandes, and GONELLI, Valéria Maria de Massarani (2013), Trajetória de construção da gestão integrada do Sistema Único de Assistência Social, do Cadastro Único e do Programa Bolsa Família para a consolidação do modelo brasileiro de proteção social. In: Programa Bolsa Família: uma década de inclusão e cidadania. Edited by CAMPELLO, Tereza and NERI, Marcelo Côrtes. Brasília: Ipea. pp. 17-18.

SILVA, Maria Ozanira da Silva e; ARAÚJO, Cleonice Correia and LIMA, Valéria Ferreira Santos de Almada (2012), Implantação, implementação e condições de funcionamento do Suas nos municípios. In: O sistema único de assistência social no Brasil: uma realidade em movimento. Edited by COUTO, Berenice Rojas; YAZBEK, Maria Carmelita; SILVA, Maria Ozanira Silva and DEGENSZAJN, Raquel Raichelis. São Paulo: Cortez. pp. 88-113.

EVANS, Peter (2011), The capability enhancing developmental state: concepts and national trajectories. Paper presented at the UNRISD-KOICA Conference Seoul, Korea. № 63.

FALLETI, Tulia (2006), Efeitos da descentralização nas relações intergovernamentais: o Brasil em perspectiva comparada. Sociologias. Ano 08, № 16, pp. 46-85. 
FARIA, Carlos Aurélio Pimenta de (ed)(2012), Implementação de políticas públicas: teoria e prática. Belo Horizonte: Ed. PUC Minas. 406 pp..

GOMES, Sandra (2010), The multi-faceted debate on decentralization and collective welfare. Brazilian Political Science Review. Vol. 05, selected edition.

GUTIERRES, Kellen Alves (2015), Projetos políticos, trajetórias e estratégias: a política de assistência social entre o partido e o Estado. PhD dissertation. Instituto de Filosofia e Ciências Humanas. Universidade de Campinas.

HILL, Michael (2005), The public policy process. New York: Routledge. 368 pp..

HILL, Michael and HUPE, Peter (2009), Implementing public policy. London: Sage Publishing. 248 pp..

HOWLETT, Michael; RAMESH, M. and PERL, Anthony. (2009), Studying public policy: policy cycles and policy subsystems. Ontario: Oxford University Press. 336 pp..

JACCOUD, Luciana; HADJAB, Patrícia Dario El-Moor, and CHAIBUB, Juliana Rochet (2009), Assistência social e segurança alimentar: entre novas trajetórias, velhas agendas e recentes desafios (1988-2008). Políticas sociais: acompanhamento $e$ análise - Vinte anos da Constituição Federal. Vol. № 17. Edited by RIBEIRO, José Aparecido Carlos. pp. 178-250.

KAZEPOV, Yuri (2005), Cities of Europe: changing contexts, local arrangements, and the challenge to social cohesion. In: Cities of Europe: changing contexts, local arrangements, and the challenge to urban cohesion. Edited by KAZEPOV, Yuri. Hoboken: Wiley-Blackwell. pp. 03-42.

KAZEPOV, Yuri and BARBERIS, Eduardo (2013), Social assistance governance in Europe: towards a multilevel perspective. In: Minimum income protection in flux. Edited by MARX, Ive and NELSON, Kennetyh. New York: Palgrave Macmillan. pp. 217-248.

LASCOUMES, Pierre and LE GALÈS, Patrick (2012), Sociologia da ação pública. Maceió: EDUFAL. 244 pp.

LAVALLE, Adrián Gurza; CASTELLO, Graziela, and BICHIR, Renata Mirandola (2008), Atores periféricos na sociedade civil: redes e centralidades de organizações em São Paulo. Revista Brasileira de Ciências Sociais. Vol. 23, № 68, pp. 73-96.

LAVALLE, Adrián Gurza; CASTELLO, Graziela, and BICHIR, Renata Mirandola (2007), Protagonistas na sociedade civil: redes e centralidades de organizações civis em São Paulo. DADOS. Vol. 50, № 03, pp. 465-498.

LAVALLE, Adrian Gurza and SZWAKO, José (2015), Sociedade civil, Estado e autonomia: argumentos, contra-argumentos e avanços no debate. Opinião Pública. Vol. 21, № 01, pp. 157-187. 
LE GALÈS, Patrick (2005), Elusive urban policies in Europe. In: Cities of Europe: changing contexts, local arrangements, and the challenge to urban cohesion. Edited by KAZEPOV, Yuri. Hoboken: Wiley-Blackwell. pp. 235-254.

LIPSKY, Michael (1983), Street-level bureaucracy: dilemmas of the individual in public services. New York: Russell Sage Foundation. 244 pp..

MADAMA, Ilaria (2013), Beyond continuity? Italian social assistance policies between institutional opportunities and agency. International Journal of Social Welfare. Vol 22, № 01 , pp. 58-68.

MARIN, T. R. (2012), Entre a caridade e os direitos sociais: a política da política de assistência social no município de São Paulo (1989-2012). Master dissertation. Faculdade de Filosofia, Letras e Ciências Humanas. Universidade de São Paulo.

MARQUES, Eduardo (2013), Government, political actors and governance in urban policies in Brazil and São Paulo: concepts for a future research agenda. Brazilian Political Science Review. Vol. 07, № 03, pp. 08-35.

O'TOOLE JR., Laurence J. (2010), Relações inteorganizacionais no processo de implementação. In: Administração pública: coletânea. Edited by PETERS, B. Guy and PIERRE, Jon. Brasília: ENAP. pp. 229-248.

PERES, Ursula Dias (2016), Public budgeting governance: an analysis of the distributive conflict based on the experience of São Paulo's municipality. Mimeo. Paper presented in the Urban Governance Seminar.

PRESSMAN, Jeffrey L and WILDAVSKY, Aaron (1984), Implementation: how great expectations in Washington are dashed in Oakland. Berkeley: University of California Press, 3rd edition 281 pp...

REZENDE, Flávio da Cunha (2012), Da exogeneidade ao gradualismo: inovações na teoria da mudança institucional. Revista Brasileira de Ciências Sociais. Vol. 27, № 78, pp. 113-130.

RODDEN, Jonathan (2005), Federalismo e descentralização em perspectiva comparada: sobre significados e medidas. Revista de Sociologia e Política. Vol. 24, pp. 09-27.

SABATIER, Paul A. (2007), The need for better theories. In: Theories of the policy process. Second Edition. Edited by SABATIER, Paul A.. Boulder: Westview Press. pp. 03-20.

SÁTYRO, Natália Guimarães Duarte and CUNHA, Eleonora Schettini Martins(2014), The path of Brazilian social assistance policy post-1988: the significance of institutions and ideas. Brazilian Political Science Review. Vol. 08, № 01, pp. 80-108.

SELLERS, Jefferey M. and LINDSTRÖM, Anders (2007), Decentralization, local government, and the welfare state. Governance: an International Journal of Policy, Administration, and Institutions. Vol. 20, № 04, pp. 609-632. 
SKOCPOL, Theda (1985), Bringing the state back: strategies of analysis in current research. In: Bringing the state back in. Edited by EVANS, Peter B.; RUESCHEMEYER, Dietrich, and SKOCPOL, Theda. Cambridge: Cambridge University Press. pp. 03-43.

SPOSATI, Aldaíza (2009), Modelo brasileiro de proteção social não contributiva: concepções fundantes. In: Concepção e gestão da proteção social não contributiva no Brasil. Text revision by RODRIGUES, Monica and COUTO, Katia Belisário. Brasília: MDS/UNESCO. pp. 13-56.

TATAGIBA, Luciana (2007), o papel do COMAS na política de assistência social em São Paulo. In: Assistência Social: controle social e política pública. São Paulo: Instituto Pólis/PUC-SP. pp. 49-113.

WINTER, Soren C. (2006), Implementation. In: Handbook of public policy. Edited by PETERS, B. Guy and PIERRE, Jon. London: SAGE Publishing. pp. 151-168.

YAZBEK, Maria Carmelita (2004), Assistência social na cidade de São Paulo: a (difícil) construção do direito. Observatório dos direitos do cidadão: acompanhamento e análise das políticas públicas da cidade de São Paulo. São Paulo: Instituto Pólis/PUCSP. 72 pp..

YAZBEK, Maria Carmelita; MESTRINER, Maria Luiza; CHIACHIO, Neiri Bruno; DEGENSZAJN, Raquel Raichelis; PAZ, Rosangela, and NERY, Vania Batista (2012), Sistema único de assistência social em São Paulo e Minas Gerais: desafios e perspectivas de uma realidade em movimento. In: $O$ sistema único de assistência social no Brasil: uma realidade em movimento. Edited by COUTO, Berenice Rojas; YAZBEK, Maria Carmelita; SILVA, Maria Ozanira Silva e and DEGENSZAJN, Raquel Raichelis. São Paulo: Cortez. pp. 161-227. 


\section{brazilianpoliticalsciencereview}

\section{ER R A T U M}

The Editor-in-Chief of the Brazilian Political Science Review manifests that the funding information of the article entitled Multi-level governance in federal contexts: the Social Assistance Policy in the City of São Paulo, authored by Renata Bichir, Gabriela Horesh Brettas and Pamella Canato, was omitted from the original publication. The first footnote of the article must read:

* http://dx.doi.org/10.1590/1981-3821201700020003

This article is one of the products of the research project "Beyond Cash Transfers? Challenges of the intersectoral articulation of social policies", coordinated by Renata Bichir at the Center for Metropolitan Studies (CEM/Cepid/Fapesp), which is funded by FAPESP (Process 2013/07616-7). 